\title{
The influence of smoking on clinical periodontal disease
}

\author{
Ina Hendiani \\ Department of Periodontic Faculty of Dentistry Universitas Padjadjaran
}

\section{ABSTRACT}

Periodontal disease has very complex and multi factor etiology. Plaque bacteria is the main cause of periodontal disease and another risk factor that also plays a role is smoking habit. Cigarette product such as nicotine can influence the development of periodontal disease that can directly and systemically damage the function of PMN cell. The research was conducted by taking a clinical examination on the smoking influence that covers the number of cigarettes and the period of smoking, and kind of cigarette to the worse of periodontal disease, and by measuring the epithel attachment loss and the bleeding index. The research was conducted to 152 male aged 20-45 years old, comprised 80 smokers and 72 non smokers at the Clinic of Faculty of Dentistry Universitas Indonesia, Jakarta. The result of the research showed that smoking gave influence on the worse of the periodontal disease. There was a profound relationship between the smoking period and the number of cigarettes consumed everyday indicated by the epithel attachment loss. Smoking did not enhance gingival bleeding. The relationship between kinds of cigarette and the gingival bleeding score and the epithel attachment loss did not show a significant bleeding.

Key words: Smoking, periodontal disease, attachment loss, papilla bleeding index.

\section{INTRODUCTION}

Periodontal disease is a chronic infection disease in periodontium tissue. The development of periodontal disease will occur when there is a balance disorder between bacteria and hospes in an appropriate local environment..$^{1,2}$ The most common periodontal disease is gingivitis which is caused by plaque. ${ }^{3}$ The continued and reoccured gingivitis can create the epithel attachment loss and alveolar bone damage. ${ }^{4.5}$

The main factor of periodontal disease is plaque bacteria, but not all plaque accumulation can create periodontal disease eventhough there are some periodonpathogen bacteria. ${ }^{2}$ Gingivitis without treatment does not always develop into periodontitis ${ }^{4,5}$ and the varied damage levels in every individual. This shows that there are other factors else than plaque that also play roles in the development of periodontal disease. ${ }^{2}$

Based on the research, some experts drew conclusions that periodontitis is a multifactor disease. Genetic factor and other risk factors interacted to each other and created varied clinical symptoms. The other risk factor that influenced periodontal disease photogenesis is the systemic condition, such as DM, osteoporosis, other systemic conditions that related to environment, like smoking habit and stress. ${ }^{2,6-9 .}$

Smoking habit plays a role on the prevalence and the worsen of periodontal disease. Some research showed that smoking habit is one out of 
two or three risk factors that can cause periodontal disease. In 1991 in USA, approximately 26\% of adult population are smokers, and in other countries the percentage of smoker is higher. ${ }^{2}$ Based on the data collected by WHO, smoking habit in Indonesia is rather high, three forth of male are smokers (75\%) and $5 \%$ of female have the same habit as well. ${ }^{10}$

Smoking habit is a very common habit in the society, so smoking status has to be considered as an important factor that can create periodontium tissue damage. Smoking habit has been deemed as the main risk factor of many periodontal disease including chronic periodontitis and progressive periodontitis. ${ }^{10,11}$

Smoke of cigarette contains more than 2000 toxic substances that can damage periodontium tissue, such as superoxide, hydrogen peroxide, monoxide gas $^{2}$, nicotine, tar, and acrolein. ${ }^{10,11}$ While the cigarette material which is highly observed is nicotine. Nicotine and its product, that is cotinin, can be found in a smoker's gingiva sulclus liquid and saliva. Low concentration of nicotine can stimulate PMN chemotaxis, and on the other hand, high concentration of nicotine can disturb fagositosis and reduce PMN activity so there will be a disorder of the protective response on bacteria. ${ }^{2,12}$

In addition, cigarette product also induces many kinds of periodontal disease by directly damaging local periodontal tissue and body response. The change of body reponse can give infection neutralization disorder and enhancing healthy periodontal tissue destruction. ${ }^{2}$ The research result on the influence of smoking on periodontium tissue is still controversial. Some other research reported that there is a direct connection between smoking and the extended depth of pocket and bone damage, and the other research reported that there is no clear relationship. ${ }^{2,13}$

\section{MATERIALS AND METHODS}

The kind of research was observational analilitic research. The subjects of the research were male patients in the Distribution and Periodontia Clinic of Faculty of Dentistry of Universitas Indonesia, Jakarta. The number of research subjects were 152,80 smokers and 72 nonsmokers.
How the research was conducted was by doing a measurement the loss of epithel attachment (Attachment Loss=AL) that was measured fro CEJ to the pocket bottom. The examination was taken by using probe in $\mathrm{mm}$, on the labial, mesiolabial, distolingual, and lingual surfaces. Teeth that were measured were 16,12,11,21,22,24,26,36,34,32, 31 ,41,42,46.

Gingival bleeding check using probe was slowly inserted into the sub gingival, a little bit to apical from gingival margin and moved horizontally along the pocket wall. Bleeding check was 30-60 seconds. The bleeding index measurement criteria (Papila Bleeding Index=PBI) of Muhlemann was as follow: (0, no bleeding; 1 , bleeding with dot shape; 2, bleeding with line shape; 3 , bleeding with triangle shape). The examination was taken by using round periodontal probe in $\mathrm{mm}$. The measured teeth were $16,12,11,21,22,24,26,36,43$ ,32,31,41,42,46 in buccal and lingual.

Smoking habit is the history of smoking that covered the number of cigarettes consumed per day (the number of cigarettes/day): kinds of cigarette and smoking period (year). Interview was conducted to the chosen patients, the questions covered the smoking habit; the history of the number of cigarettes consumed per day (in number), smoking period (in year), kinds of cigarette (filter or non filter).

The data was analyzed statistically. The statistic tests used were: chi-square Kruskal Wallis test to compare the $\mathrm{PBI}$ score, $\mathrm{AL}$ based on the number of cigarettes per day and the smoking period. Mann-Whitney test to compare the clinic variable (PBI, $\mathrm{AL}$ ) between smokers and nonsmokers, and the $\mathrm{PBI}, \mathrm{AL}$ score between kinds of cigarette, filter and non filter. Correlation count of Rank-Spearman to find out the relationship of the number of cigarettes consumed per day and the smoking period with $\mathrm{PBI}$ and $\mathrm{AL}$ scores, and also to find out the relationship between clinical variable $\mathrm{PBI}$ and $\mathrm{AL}$ scores on smokers and non smokers.

\section{RESULT}

The research was conducted in the Distribution and Periodontia Clinic of Faculty of Dentistry of Universitas Indonesia, Jakarta. The subjects of the research were between 20-45 
Table 1. The difference between PBI, AL scores in groups of smoker and non smoker.

\begin{tabular}{ccccc}
\hline Variable & $\begin{array}{c}\text { Smoker } \\
(\mathrm{n}=80)\end{array}$ & $\begin{array}{c}\text { Non smoker } \\
(\mathrm{n}=72)\end{array}$ & $\mathrm{Zm}-\mathrm{W}$ & $\mathrm{P}$ \\
\hline $\mathrm{PBI}$ & & & & \\
$\mathrm{X}(\mathrm{SD})$ & $0.85(0.58)$ & $0.78(0.56)$ & & \\
Median & 0.81 & 0.74 & 0.773 & 0.439 (NS) \\
Range & $0-3.15$ & $0-229$ & & \\
$\mathrm{AL}$ & & & & \\
X (SD) & $0.40(0.88)$ & $0.64(061)$ & & \\
Median & 1.39 & 0.42 & 5.524 & $<0.001$ (NS) \\
Range & $0-3.41$ & $0-2.05$ & & \\
\hline
\end{tabular}

Table 2. The change of the worse of AL, PBI in smokers based on the number of cigarettes consumed per day.

\begin{tabular}{|c|c|c|c|}
\hline \multirow{2}{*}{\multicolumn{2}{|c|}{ Total/day }} & \multicolumn{2}{|c|}{ Variable } \\
\hline & & \multirow{2}{*}{$\frac{\text { PBI }}{0.85(0.68)}$} & \multirow{2}{*}{$\frac{\mathrm{AL}}{0.88(0.68)}$} \\
\hline $1-5(n=28)$ & $X(S D)$ & & \\
\hline & ME & 0.79 & 0.69 \\
\hline & Range & $0-3.15$ & $0-2.16$ \\
\hline \multirow[t]{3}{*}{$6-10 \quad(n=19)$} & $X(S D)$ & $0.857(0.68)$ & $1.23(0.85)$ \\
\hline & ME & 0.79 & 1.09 \\
\hline & Range & $0.08-1.86$ & $0.16-2.83$ \\
\hline \multirow[t]{3}{*}{$11-15(n=20)$} & $X(S D)$ & $0.87(0.54)$ & $1.89(0.67)$ \\
\hline & ME & 0.84 & 1.89 \\
\hline & Range & $0-2,18$ & $0.67-3.04$ \\
\hline \multirow[t]{3}{*}{$16-20(n=5)$} & $X(S D)$ & $0.75(0.38)$ & $1.83(0.02)$ \\
\hline & ME & 1 & 2.18 \\
\hline & Range & $0.29-1.07$ & $0.75-3.02$ \\
\hline \multirow[t]{7}{*}{$21+(n=8)$} & $X(S D)$ & $0.82(0.55)$ & $2.17(0.67)$ \\
\hline & ME & 1.10 & 2.19 \\
\hline & Range & $0-1.39$ & 0.7141 \\
\hline & & (NS) & \\
\hline & $X 2 K-W$ & $0.425(0.55)$ & 23.943 \\
\hline & $P$ & 0.980 & $<0.001$ \\
\hline & & (NS) & (S) \\
\hline
\end{tabular}

Table 3. The difference of worse in AL, PBI in non filter and filter cigarette smokers.

\begin{tabular}{cccc}
\hline \multicolumn{2}{c}{ Cigarettes type } & PBI & AL \\
\hline Non filter & $X(S D)$ & $0.78(0.57)$ & $1.55(0.97)$ \\
$(\mathrm{n}=27)$ & $M E$ & 0.82 & 1.5 \\
& Range & $0-1.86$ & $0-3.05$ \\
Filter & $X(S D)$ & $0.88(0.57)$ & $1.33(0.97)$ \\
$(\mathrm{n}=53)$ & $\mathrm{ME}$ & 0.79 & 1.35 \\
& Range & $0-1.86$ & $0.11-3.41$ \\
& Zm-w & 0.656 & 0.982 \\
& $\mathrm{P}$ & 0.512 & 0.326 \\
& & $(\mathrm{NS})$ & $(\mathrm{NS})$ \\
\hline
\end{tabular}

Table 4. The change of worse in AL, PBI in smokers based on smoking period.

\begin{tabular}{|c|c|c|c|}
\hline \multirow{2}{*}{\multicolumn{2}{|c|}{ Smoking period (Year) }} & \multicolumn{2}{|c|}{ Variable } \\
\hline & & \multirow{2}{*}{$\begin{array}{c}\text { PBI } \\
0.71(0.36)\end{array}$} & \multirow{2}{*}{$\frac{\mathrm{AL}}{1.0(0.94)}$} \\
\hline $0-2(n=9)$ & $X(S D)$ & & \\
\hline & $\mathrm{Me}$ & 0.75 & 0.32 \\
\hline & Range & $0.21-1.29$ & $0.18-2.41$ \\
\hline \multirow[t]{3}{*}{$3-4(n=6)$} & $X(S D)$ & $1.08(0.44)$ & $1.06(0.55)$ \\
\hline & Me & 1.06 & 1.12 \\
\hline & Range & $0.43-1.69$ & $1.25-1.70$ \\
\hline \multirow[t]{3}{*}{$5(n=7)$} & $X(S D)$ & $0.94(1.06)$ & $0.94(0.82)$ \\
\hline & $\mathrm{Me}$ & 0.64 & 0.66 \\
\hline & Range & $0.08-3.15$ & $0.11-2.18$ \\
\hline \multirow[t]{3}{*}{$6-9(n=16)$} & $X(S D)$ & $0.68(0.52)$ & $0.94(0.50)$ \\
\hline & Me & 0.66 & 0.91 \\
\hline & Range & $0-1.82$ & $0.15-1.86$ \\
\hline \multirow[t]{3}{*}{$10-14(n=21)$} & $X(S D)$ & $0.75(0.57)$ & $1.60(1.0)$ \\
\hline & $\mathrm{Me}$ & 0.79 & 1.82 \\
\hline & Range & $0-2.18$ & $0-3.04$ \\
\hline \multirow[t]{6}{*}{$15+(n=21)$} & $X(S D)$ & $1.04(0.52)$ & $1.98(1.0)$ \\
\hline & $\mathrm{Me}$ & 1.07 & 2.09 \\
\hline & Range & $0-1.86$ & $0.75-3.41$ \\
\hline & $\mathrm{X}^{2} \mathrm{~K}-\mathrm{W}$ & 7.002 & 18.617 \\
\hline & $P$ & 0.220 & 0.002 \\
\hline & & (NS) & (S) \\
\hline
\end{tabular}

Table 5. The relation between the numbers of cigarettes/ day; smoking period with $\mathrm{AL}$ and $\mathrm{PBI}$.

\begin{tabular}{cccc}
\hline No & $\begin{array}{c}\text { Correlation of } \\
\text { Variable }\end{array}$ & rs & P \\
\hline 1 & $\mathrm{PBI}><$ Total cigarettes & 0.045 & 0.69 (NS) \\
2 & $\mathrm{AL}><$ Total cigarettes & 0.538 & $<0.001(\mathrm{~S})$ \\
3 & $\mathrm{PBI}><$ smoking period & 0.146 & $0.198(\mathrm{NS})$ \\
4 & $\mathrm{AL}><$ smoking period & 0.452 & $<0.001$ \\
\hline
\end{tabular}

Note: NS, Non significant; S, Significant 
years of age, comprised 152 male; 80 smokers and 72 non smokers.

Based on the statistic test using MannWhitney test in Tab. 1, it could be seen that there was a significant difference in $\mathrm{AL}$ score between smoker and non smoker groups, in which the smoker group's average and median were higher than the non smoker's $(p<0,001)$. On the other hand, stastically, there was no significant difference on the PBI score between the smoker and non smoker groups $(p=0.439)$.

From this research, a conclusion could be drawn that the worse of periodontal disease by measuring the epithel attachment loss score in smokers was higher that of those who are non smokers, but the bleeding index score did not show any significant difference.

Based on the Chi-square Kruskal-Wallis statistic test, the clinical examination result on smokers for $A L$ variable $(p<0,001)$ had a strong relationship with the number of cigarettes consumed per day, that is, the more cigarette consumed per day, the epithel attachment loss score would get higher. Statistically, the bleeding index was not significantly related to the number of cigarettes consumed per day $(p<0,05)$ (Tab. 2).

The relationship between clinical examination result on smokers with kinds of cigarette based on Mann-Whitney statistic test as seen in table 3 , the result showed that there was no significant difference between filter and non filter cigarettes in AL, PBI scores.

It can be concluded that smoking habit based on kinds of cigarettes, filter and non filter, was not significantly related to the worse of periodontal disease (AL score and PBI score) (Tab. 3).

The relationship between clinical examination result with smoking period showed that there was a very significant relation between $\mathrm{AL}$ and smoking period $(\mathrm{p}=0,002)$.

It can be concluded that the longer the smoking period, the epithel attachment loss would get higher. The bleeding index to the smoking period was statistically not significant $(p>70,005)$. (Tab. 4).

Further analysis was conducted in order to find out the relationship between $\mathrm{AL}$ and $\mathrm{PBI}$ with number of cigarettes consumed per day and smoking period using Rank-Spearman correlation analysis. The result was, there was a very strong relationship between $\mathrm{AL}$ with number of cigarettes and the smoking period $(\mathrm{p}<0,001)$.

It can be concluded that there was a tendency of the increase of epithel attachment loss with the increase of number of cigarettes per day (Spearman=0,538; $<<0,001)$, and a tendency of the increase of epithel attachment loss with the smoking period (year) (Spearman = $0,452 ; p<0,001)$.

\section{DISCUSSION}

Smoking is one of the main risk factors to the prevalence and the increase of the worse of periodontal disease. ${ }^{2,6,9,14,15}$ In cigarette, nicotine is sit toxic and vasoactive. Nicotine is able to influence the development of periodontal disease directly and systemically through blood circulation and saliva. The nicotine effect in cigarette can damage the PMN function in neutralizing infection and stimulating body immune in order to destroy other healthy tissues.

This research showed that the gingival bleeding index on smokers was clinically higher than on those who were non smokers, but there was no significant difference. The result of this research was supported by the research held by Danielsen ${ }^{16}$ which stated that the gingival index of smokers did not have any difference from the gingival index of non smokers. ${ }^{16}$

This research was also supported other research that stated the periodontal disease on smokers having gingival bleeding and gingival ulcer were less than on those who were non smokers. ${ }^{17,18,19,20}$ Recent research using heat diffusion technique to measure blood flow to gingival showed the reduction of blood flow, inducing oederm and inflammation on smokers. 2,18 Clinical description of periodontal health, such as gingival bleeding and ulcer changed on smokers comparing to non smokers. These changes followed the physiology change that was related to disease process. $^{13}$

Nicotine could give influence directly on the development of periodontal disease by damaging normal periodontium tissue cells. ${ }^{2,18}$ Nicotine could be stored and released from fibroblast. The fibroblast that was contaminated by nicotine had 
different morphology and underwent the change of ability to attach on root surface. ${ }^{2}$ Nicotine had vasoconstriction effect, not only in peripheral circulation but also in the coroner, and gingival vein. ${ }^{11,17,21}$ Due to the local or systematic effect of the substances contained in cigarette, there were less redish and gingival bleeding in smokers compared to non smokers. This showed that smoking was environment influence that modified gingivitis response to plaque.

The result of the research showed that gingival bleeding in smokers due to the numbers of cigarette consumed per day and the long period of smoking did not enhance gingival bleeding, this meant the numbers of cigarette consumed per day and the smoking period did not influence gingival bleeding. This research was supported by the research conducted by Ludwick and Massler ${ }^{22}$ that did not find any relationship between gingival ulcer and the numbers of cigarette consumed per day and the smoking period. ${ }^{22}$

This research showed that smoking habit influenced the worse of periodontal disease, it could be noticed by the loss of epithel attachment in smokers was higher than in non smokers with a very significant difference. ${ }^{14}$ The result of this research was also supported by the research conducted by Liden and Mullay ${ }^{14}$ that indicated the epithel attachment loss in smokers was higher than in non smokers and the numbers of cigarette consumed per day influenced the epithel attachment loss. The more cigarettes consumed per day, the epithel attachment loss would increase. This was supported by some researchers ${ }^{12,24,25}$ that reported the increase of epithel attachment loss was influenced by the increase of cigarette consumption. ${ }^{13.23}$

The result of this research showed the smoking period (in year) had a profound influence on the worse of periodontal disease. This was proved by the longer the smoking period, the bigger the chance of losing the epithel attachment $(p<0,001)$.

This result was supported by the research conducted by Haber and Kent $^{18}$ which stated that there was a direct relationship between the smoking period (year) with periodontal, but the relationship of plaque score and calculus score was not noticed. ${ }^{26}$ The research conducted by Grossi et al. ${ }^{12}$ indicated that the longer the smoking period, the bigger chance of losing the attachment. ${ }^{12}$ History of smoking period and the number of cigarettes had a close relationship to the worse of epithel attachment loss (correlation Spearman $=0,452, p<0,001$, for smoking period; correlation Spearman $0,538, p<0,001$ for the numbers of cigarette per day). This was supported by the research report of cross sectional and longitudinal that ensured the consistent and positive relationship between smoking habit and epithel attachment loss.

The strong relationship between smoking and the epithel attachment loss could be explained by come biological phenomenon. Cigarette contained nicotine and its product had vasoconstriction effect on gingival vein. ${ }^{13,21}$ Smoking (nicotine) could reduce the PMN functional activity and macrophage in saliva and gingival liquid by reducing chemotaxis force and PMN phagocyte in blood and tissue. Consequently, nicotine pressed the phagocyte force which was a kind of protective response on pathogen bacteria. ${ }^{13,21}$

This research showed that there was no significant difference influence on the epithel attachment loss score, plaque score, calculus score and gingival bleeding between non filter and filter cigarette. The result of this research was also indicated the relationship between non filter and filter cigarettes to the clinical parameter with the difference on the number of cigarettes and the smoking period. If the number of cigarettes and the smoking period were equal then the relationship of kinds of cigarette and the clinical parameter could be more accurate. Both kinds of cigarettes, non filter or filter had the same bad effect on periodontium tissue's health. The filter in cigarette could not filter toxic materials contained in it.

\section{CONCLUSION}

Based on this research, smoking habit influenced the worse of periodontal disease. This was indicated by the increase of epithel attachment loss of smokers was higher than in those who were non smokers, but it did not give any influence on gingival bleeding. The number of cigarettes consumed per day gave a profound influence on the epithel attachment loss, in other 
words, the more cigarettes consumed per day, the higher risk of epithel attachment loss, and the number of cigarettes consumed per day had a close relationship to the epithel attachment loss. The smoking period (year) also influenced the epithel attachment loss and bleeding score even though there was a clinical increase but, statistically, there was no significant difference. This showed that there was a relationship between the smoking period and the epithel attachment loss, but there was no relationship on gingival bleeding. Kinds of cigarette had no connection to the epithel attachment loss and gingival bleeding.

\section{REFERENCES}

1. Socransky SS, Haffajee AD. Microbiology and immunology of periodontal disease. Periodontology 2000; 1994. p. 5,7-18,5261,66-76,78-97.

2. Wilson TAG, Kornman KS. Fundamental of periodontics. Chicago: Quintessence; 1996. p. 281-317.

3. Ranney RR. Classification of periodontal diseases. Periodontology 2000 1993;2:13-21.

4. Carranza FA, Newman MG. Clinical periodontology. $8^{\text {th }}$ ed. Philadelphia: W.B. Saunders Co.; 1996. p. 169.

5. Loe H. Periodontology disease-a brief historical perspective. Periodontology 2000 1993;2:712.

6. Page RC, Offenbacher S, Schroder HE, Seymor GJ, Kornman KS. Advances in the pathogenesis of periodontitis summary of developments clinical implication and future directions. Periodontology 2000 1997;14:216-41.

7. Kemal Y. Paradigma baru penyakit periodontal sebagai dasar dalam melakukan terapi periodontal. Pengendalian infeksi mukosa mulut dan jaringan periodontal. Kumpulan Makalah Pertemuan Ilmiah PDGI; 1997 Dec 6; Bandung-Indonesia. Bandung: Persatuan Dokter Gigi Indonesia Cabang Bandung; 1997. p. 41-5.

8. Bartold PM. Periodontitis and risk factors risk factors in Asian Pacific populations. Brisbane: Asian Pacific Society of Periodontology; 1996. p. 3-8.

9. Genco FJ, and Loe $\mathrm{H}$. The role of systemic conditional and disorders in periodontal disease. Periodontology 2000. 1993;2:98-101.

10. Aditama TY. Rokok dan kesehatan. $3^{\text {th }}$ ed. Jakarta: UI PRESS; 1997. 18-26,35-44.

11. Sitepoe M. Usaha mencegah bahaya merokok. Jakarta: Grasindo; 1997. p. 17-24,49-56.

12. Grossi SG. Zambon JJ, Ho AW, Koch G, Dunfard RG, Machtii EE et al. Assessment of risk for periodontal disease risk indication for attachment loss. J Periodontol 1994;65:2607.

13. Rivera F, Hidalgo. Smoking and periodontal disease. A review of the literature. J Periodontology 1986;57:617-23.

14. Linden GJ, Mullaly BH. Cigarette smoking and periodontal destruction in your adult. J Periodontology 1994;65:718-23.

15. Horning GM, Hatch CL, Cohen ME. Risk indicators for periodontitis in a military treatment population. J Periodontology 1992;63:297-302.

16. Danielsen BF, Manji M. Nagerkeke O, Fejerkov, Baelum. Effect of ciagarette smoking on the transtition dynamics in experimental gingivitis. J Clin Periodontolology 1990;17:159-64.

17. Kornman KS, Loe H. The role of local factors in the etiology of periodontal disease. Periodontology 2000 1993;2:83-91.

18. Haber J, Kent RL. Cigarette smoking in a periodontal practice. J Periodontology 1992;63:100-6.

19. Bergstron J. Floderus-Myrhed B. Co twin control study of the relationship between smoking and some periodontal disease factors. Commun Dent Oral Epidemial 1983;11:113-6.

20. Preber $\mathrm{H}$, Bergstrom J. Occurance of gingival bleeding in smoker and non-smoker patients. Acta Odontology Scand 1985;43:315-20.

21. Prayitno SW. The association between biodata and periodontal status among young adult Indonesians, risk factors in Asian Pacific populations. Brisbane: Asian Pacific Society of Periodontology 1996. p. 22-30.

22. Ludwick W, Massler M. Relation of dental caries experience and gingivitis to cigarette smoking in males 16 to 21 years old. J Dent Res 1952;31:319-22.

23. Bergstrom J, Eliasson S, Preber H. Cigarette smoking and periodontal bone loss. J Periodontology 1991;62:242-6.

24. Arno A, Schei O, Lavdal A, Waerhaug J. 
Alveolar bone loss as a functionof tobacco consumption. Acta Odontol Scand 1959.

25. Hancock EB. Review: Prevention. Annals of Periodontology 1996;1(1):225-6.
26. American Academy of Periodontology. Concencus report on perodontal diseases: pathogenesis and microbial factors. World Workshop in Periodontics; Annals of Periodontology 1996:927. 